\title{
INTERDISZCIPLINÁRIS ASSZOCIÁCIÓK VIZSGÁLATA A MESTERSÉGES INTELLIGENCIÁVAL KAPCSOLATBAN
}

\section{Szerző:}

Mező Ferenc $(\mathrm{PhD})$

Eszterházy Károly Egyetem

Mező Katalin (PhD)

Debreceni Egyetem

Első szerző e-mail címe:

ferenc.mezo1@gmail.com

\section{Lektorok:}

Csukonyi Csilla (PhD)

Debreceni Egyetem

Szabóné Balogh Ágota (PhD)

Gál Ferenc Fóiskola

...és további két anonim lektor

\section{Absztrakt}

Jelen tanulmány egy nemzetközi interdiszciplináris konferencia résztvevőinek asszociációit elemzi a mesterséges intelligencia (MI) témával kapcsolatban. Minta: $\mathrm{n}=202$ válasz. Módszer: online adatgyűjtés, az adatfeldolgozás a válaszok gyakoriságának és tartalmainak elemzésére vonatkozott. Eredmények: a válaszadási ráta alacsony volt (a várható szám kb. 30\%-a), a válaszok 85,71\%-a az „MI mint lehetséges eszköz” kategóriába volt sorolható és 14,29\%-uk tartozott az „MI és a világ közötti kölcsönhatás” kategóriába. nem érkezett válasz az „MI mint kutatási cél" kategóriába.

Kulcsszavak: mesterséges intelligencia, MI, interdiszciplináris kutatás

Diszciplina: interdiszciplináris

\begin{abstract}
EXAMINATION OF INTERDISCIPLINARY ASSOCIATIONS RELATED TO ARTIFICIAL INTELLIGENCE

The present study analyzes the reflections of the participants of an international interdisciplinary conference about the topic of artificial intelligence (AI). Sample: $n=202$ answers. Method: Data collection was done by online, data processing was done by analyzing of frequency and contents of answers. Results: The response rate was low (appr. 30\% of the expected number), $85,71 \%$ of the responses were in the category 'AI as a potential tool', and $14,29 \%$ were in the category 'Interaction between AI and the world'. There were no responses in the case of 'AI as a research goal'.
\end{abstract}

Keywords: artificial intelligence, AI, interdisciplinary research

Discipline: interdisciplinary

Mező Ferenc és Mező Katalin (2020): Interdiszciplináris asszociációk vizsgálata a mesterséges intelligenciával kapcsolatban. Mesterséges intelligencia - interdiszciplináris folyóirat, II. évf. 2020/1. szám. 9-31. doi: 10.35406/MI.2020.1.9 
A „mesterséges intelligencia” (MI, vagy: artificial intelligence, AI) minden tudományterület felől megközelíthető, valóban interdiszciplináris együttműködéseket magába foglaló kutatási téma. Ennek magyarázata az lehet, hogy (Mező, 2019; lásd: 1. ábra):

a) néhány tudományág (például: informatika, matematika, filozófia, nyelvészet, műszaki tudományok stb.) a mesterséges intelligencia megalkotására, mint célra tekinthet; b) minden tudományág használhatja kutatási eszközként a mesterséges intelligenciát;

c) számos tudományág (például: szociológia, pszichológia, gazdaságtudomány, politológia stb.) kutatási témájának tekintheti a mesterséges intelligencia és a világ interakcióját, egymásra gyakorolt hatását.

A mesterséges intelligenciának ezen kívül művészeti, sportbeli, ipari és hétköznapi alkalmazási területei is lehetnek.

1. ábra: A mesterséges intelligencia (MI) kutatások lehetséges orientációja (forrás: Mezőo, 2019)

\begin{tabular}{|c|c|c|c|}
\hline \multirow[b]{2}{*}{ SZEMPONT } & \multicolumn{3}{|c|}{ MEGKÖZELITES } \\
\hline & $\begin{array}{c}\text { Cé1 } \\
\text { jellegũ }\end{array}$ & $\begin{array}{l}\text { Eszköz } \\
\text { jellegú }\end{array}$ & $\begin{array}{l}\text { Hatás- } \\
\text { orientált }\end{array}$ \\
\hline Formula: & MII = cél & $\mathrm{MII}=$ eszköz & MII ড Világ \\
\hline Központi kérdés: & $\begin{array}{c}\text { Mi az MII? } \\
\text { Hogyan alkotható } \\
\text { MII? }\end{array}$ & Mire használható az MII? & $\begin{array}{c}\text { Milyen (kölcsön)hatás } \\
\text { van az MII és a világ } \\
\text { között? }\end{array}$ \\
\hline
\end{tabular}

Kapcsolódó

diszciplinák: matematika, informatika, kibernetika, pszichológia minden tudományterület

+ ipari, üzleti, múvészeti, sport és hétköznapi kapcsolódási lehetóségek

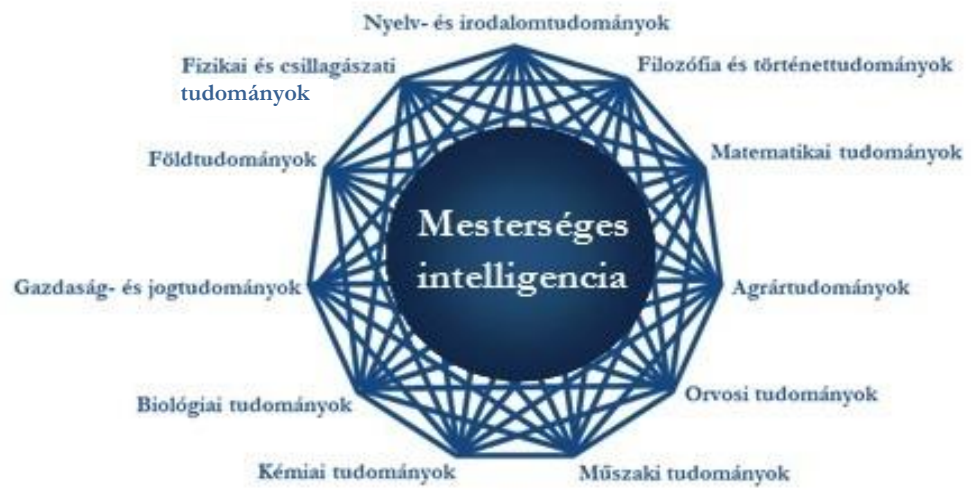


Az alábbiakban egy e-konferencia MI-re vonatkozó nyilvános kérdése és az arra adott válaszok elemzése alapján szeretnénk demonstrálni az MI téma interdiszciplináris és felhívó jellegét.

Terjedelmi korlátok miatt és az önismétlés elkerülése végett Mező (2019) mûvét tekintjük jelen vizsgálat elméleti megalapozásának.

\section{Kérdések és hipotézisek}

Arra voltunk kíváncsiak, hogy a „Mi a kapcsolat a prezentációja és a mesterséges intelligencia (pl. robotok, tanulni képes algoritmusok stb.) között?" kérdés, mint hívóinger mennyi, s milyen reakciókat vált ki egy interdiszciplináris összetételű és jellegű e-konferencia előadói közösségéből?

E kvantitatív és kvalitatív adatfeldolgozást egyaránt magába foglaló kérdéssel kapcsolatos hipotéziseink:

1. hipotézis: várakozásunk szerint a konferencia minden résztvevője választ ad a kérdésre. A hipotézis indoklása: egyrészt a téma interdiszciplináris kapcsolódási lehetőséget nyújt minden tudományág képviselőjének; másrészt tudományos konferenciákon (még akkor is, ha e-konferenciáról van szó) elvárható és megszokott a nyilvános vitában a válaszadás.

2. hipotézis: a „nincs kapcsolat a témám és a mesterséges intelligencia témakör között"” jellegû válaszok helyett a válaszadók kutatási témája és a mesterséges intelligencia cél, eszköz vagy világgal való kölcsönhatására rámutató válaszokat tapasztalunk az esetek összességében, de legalább 90\%-ában. Hipotézis indoklása: a „mesterséges intelligencia” témát minden tudományág szempontjából kutatható és/vagy hasznosítható témának véljük.

\section{Minta}

A vizsgálatban a 2020. március 20-2020. május 1. között megrendezésre kerülő $V$. Nemzetközi Interdiszciplináris Konferencián közzétett $n=202$ prezentáció szerzői által adott válaszokat tekintjük mintának. Megjegyzendő, hogy a társszerzőségre való tekintettel a prezentációk száma kevesebb, mint a szerzők (274 fő) száma, s nem szerzőnként, hanem prezentációnként került sor a válaszadásra a konferencia során.

A mintavétel kényelmi jellegű volt, s nem tekinthető reprezentatívnak. Ugyanakkor úgy véljük, hogy az eredményekből óvatos, további ellenőrzést igénylő következtetések mégis levonhatók.

A mintát sem nemenként, sem korcsoportonként, sem nemzetiségenként vagy tudományterületenként nem tagoltuk jelen vizsgálatban (minderre egy későbbi tanulmányban kerülhet majd sor).

A résztvevők tájékoztatva voltak arról, hogy a válaszok nyilvánosan közzé lesznek téve. Tekintettel a konferencia nyilvános jellegére, a válaszokban rejlő tudományos teljesítmények, és a szerzői elsőbbségi kérdések kezelésére, a válaszadói anonimitás biztosítására nem törekedtek a szervezők. A konferencián történő részvétel és a válaszadásba történő bekapcsolódás is önkéntes volt.

\section{Módszer}

Az V. Nemzetközi Interdiszciplináris Konferencia a COVID-19 (koronavírus-betegség) 
világjárványra való tekintettel e-konferencia formájában valósult meg 2020. első felében (2. ábra).

2. ábra: a konferencia résztvevơi köre országonként, s szervezöi köre intézményenként (forrás: Mezó és Mezó, 2020a, 59. o.)

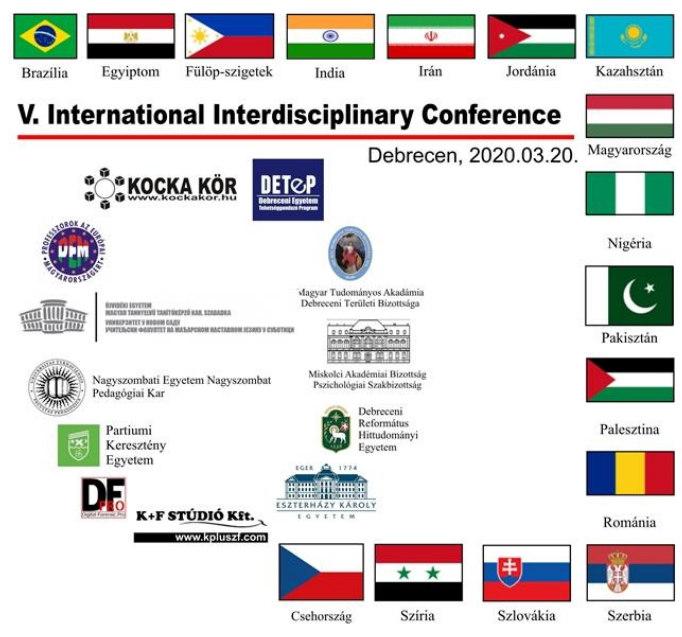

Az adatgyüjtés és -feldolgozás az alábbi ütemezésben történt:

2020. március 15-2020. március 19. között tölthették fel prezentációikat a résztvevők,

2020. március 20-2020. április 1. között az érdeklődők nyilvánosan kérdezhettek. Ekkor történt meg a mesterséges intelligencia és a saját téma közötti összefüggésre történő rákérdezés is - a kérdés minden prezentáció (első)szerzőjének fel lett téve.

2020. április 1-2020. április 15. között küldhették meg válaszukat a szerzók emailben a szervezőknek.

Ezután kezdődhetett meg a válaszok kvantitatív és kvalitatív elemzése. A válaszok kvantitatív elemzése során a válaszok számára vonatkozó, valamint a ,nincs kapcsolat a két témakör között” jellegú (további kvalitatív elemzéssel nem értékelhető) és a két témakör között kapcsolatot bemutató (továbbiakban: értékelhető) válaszok gyakoriságát ellenőriztük leíró statisztikai adatokkal, illetve khi-négyzet próbával.

A kvalitatív elemzéskor az értékelhető válaszokat három tartalmi kategóriába soroltuk, ezek:

1) a mesterséges intelligenciára, mint kutatási célra tekintő válaszok (példa: a kutatás célja egy mesterséges intelligencia létrehozása);

2) a mesterséges intelligenciára, mint eszközre tekintő válaszok (példa: egy mesterséges intelligenciát eszközként használnak fel egyéb témára vonatkozó kutatásban);

3) a mesterséges intelligencia és a világ kölcsönhatására vonatkozó válaszok (példa: hogyan változtatja meg a hétközapi, üzleti, tudományos stb. életet a mesterséges intelligencia elterjedése, s fordítva: miként hatnak a mesterséges intelligencia kutatására/elterjedésére a világ eseményei).

A kategóriába sorolást két személy évgezte egymástól függetlenül. Véleménykülönbség esetén konzultáció során történt döntés egy válasz adott kategóriába sorolásáról.

Ezt követően az egyes kategóriákba érkezett válaszok gyakoriságát vetettük össze (tehát kvantitatív adatokhoz is jutottunk, azokat is használtuk).

A statisztikai elemzéshez az SPSS matematikai statisztikai programot alkalmaztuk. 


\section{Eredmények}

A válaszok kvantitativ elemzése. Az első hipotézisünk nem igazolódott. Noha feltételeztük, hogy a konferencia összes (első)szerzője válaszolni fog a feltett kérdésre - ha többre nem is, de legalább egy „véleményem szerint nincs kapcsolat a témám és a mesterséges intelligencia között" tartalmú válaszra számítani lehetett -, ez azonban nem történt meg.

A 202 prezentációval kapcsolatban várható 202 válasz helyett mindössze 63 válasz érkezett (ez 31,19\%-os válaszadási gyakoriságot jelent). A beérkezett válaszok között 21 „nincs kapcsolat” jellegű volt, s 42 volt a két témakör közötti valódi interakcióra vonatkozó, a továbbiakban tartalmilag értékelhetô válasz. E 42 válasz az összes várható ( $\mathrm{n}=202)$ válasznak mintegy ötöde (20,79\%-a) és a valóban beérkezett $(n=63)$ válasz kétharmada (66,67\%-a - lásd: 3. ábra). Tehát a 2. hipotézis sem nyert megerősítést.

3. ábra: „Mi a kapcsolat a prezentációja és a mesterséges intelligencia (pl. robotok, tanulni képes algoritmusok stb.) között?" kérdésre $n=202$ prezentáció szerzoôi által adott válaszok eloszlása (forrás: a Szerzók)

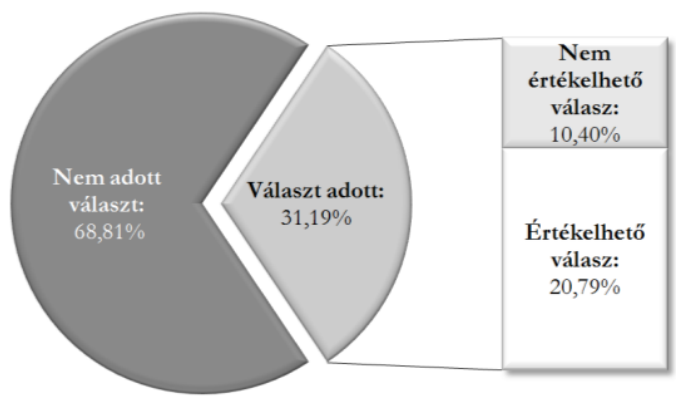

Nem meglepő módon szignifikáns különbség van a választ adó/nem adó (első)szerzők száma között, akkor is, ha például 0,9:0,1 arányban súlyozzuk a várható értékeket (khinégyzet $=776,318 ; d f=1 ; p<0,001)$, és akkor is, ha 0,5:0,5 arányban (khi-négyzet $=28,594 ; d f$ $=1 ; p<0,001)$.

Szignifikáns a különbség az értékelhető/nem értékelhető válaszok között is (0,9:0,1 arányú súlyozás esetében: khi-négyzet $=38,111 ; d f=1 ; p<0,001$; egyenlő arányú előfordulást feltételezve pedig khi-négyzet = 7,000; $d f=1 ; p=0,008)$.

Amint az a 4. ábrán is látható, a 42 értékelhető válasz közül...

...0 volt a mesterséges intelligencia kutatását célként tekintő csoportba sorolható;

...36 válasz (az értékelhető válaszok 85,71\%-a) a mesterséges intelligenciára, mint eszközre tekintett;

4. ábra: a mesterséges intelligenciára, mint célra vagy eszkö̈re vagy a világgal kölcsönható tényezöre reflektáló $(n=42)$ válaszok gyakorisága (forrás: a Szerzők)

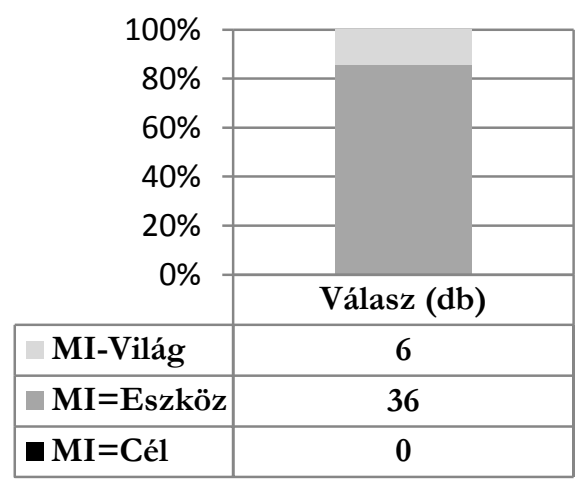


...a mesterséges intelligencia és a világ kölcsönhatása kategóriába 6 válasz (14,29\%) volt besorolható (az utóbbi két kategória esetében: khi-négyzet $=21,429 ; d f=1 ; p<0,01)$.

\section{Megvitatás}

A megvitatás során először a kvantitatív, majd a kvalitatív adatelemzés eredményeivel kapcsolatos felvetéseket foglaljuk össze.

\section{A kvantitativ adatelemzés \\ eredményeinek megvitatása}

Az alacsony válaszadási hajlam hátterében álló lehetséges (egymást nem kizáró, sőt akár erôsítő) okok például a vélt/remélt valószínűségük szerinti csökkenő sorrendben:

a) A járványbelyzet okozta stressz, élet-és/vagy munkamód-váltással járó következményei akadályoz̧hatták a válaszadást. A válaszadási időszakban (is) a COVID-19 (koronavírus-betegség) okozta járvány világszerte megszorításokat hozott életünkbe. E megszorítások egy része életmódváltással járt. Például több országban kijárási korlátozás/tilalom volt érvényben, változtak a személyes interakcióra vonatkozó ajánlások (kézfogás, testi kontaktus kerülése került javaslatra), szűkültek a vásárlási vagy a vásárlási időbeosztásra vonatkozó lehetôségek (az, hogy ki, mikor, milyen boltban vásárolhat?), de itt említhetjük az arcmaszkok használatára vonatkozó ajánlást/kötelezettséget is. Sok szakterület esetében a megszokott munkamód és -lehetőség is változott. A tudományos konferenciák közönségét alkotó kutatói, oktatói, doktoranduszi, hallgatói kör életében a válaszadási időszakban például távoktatás, illetve otthoni munkavégzés volt jellemző. A válaszadás feltételezte, hogy a potenciális válaszadók kezelni tudják a járványhelyzet és életmódváltozás okozta stresszt, uralni tudják a megváltozott munkafeltételek megváltozott időbeosztását (pedagógusok, oktatók esetében a távoktatás feltételrendszerének, tananyagának kidolgozása, s esetenként a távoktatás online megvalósítása nagy munka- és időterhet jelentett). Ilyen körülmények között előfordulhatott, hogy rangsorolni kellett az egészségmegőrzésre, a munkavégzésre és az e-konferenciát érintő válaszadásra vonatkozó feladatokat, s az előző két tevékenység prioritást élvezett a többség esetében, a válaszadás pedig (sajnálatos, de az egyes esetek. A válaszolók esetében pedig olyan élethelyzettel számolhatunk, ami szerencsés módon megengedte a nyilvános válaszadás „luxusát” (például: rendelkezésre állt idő- és internetkapcsolat is).

b) Az e-konferenciával járó helyzet szokatlansága is állhat a kisgyakoriságú válaszadás háttérben: az e-konferencia eltér a hagyományos, közvetlen személyes jelenléttel járó konferencián tapasztalható helyzettől. Egy személyes jelenléttel járó konferencián az egyes prezentációk (vagyok azok összessége) után jellemző a nyilvános vita, amikor az előadók élőszóban válaszolnak a nekik feltett kérdésekre. Ehhez képest a szóban forgó e-konferencián írásban kellett válaszolni, amire ugyanakkor nem másodpercek álltak rendelkezésre, hanem 15 nap. Mindent összevetve az bizonyosnak tekinthető, hogy jelen e-konferencia válaszadási módja és időbelisége eltért a személyes jelenlétet igénylő konferenciákétól.

c) A konferencia-teljesitmény prezentációra történó sqükitése is csökkentheti a válaszadási hajlamot. 
Egy hagyományos, személyes jelenléttel járó konferencia-teljesítmény magában foglalja:

1) a konferenciára jelentkezés feltételeinek teljesítését (ilyenek: regisztráció, esetleges absztrakt beküldése és elfogadása, részvételi díj befizetése, s mindezek határidejének betartása);

2) a megjelenést a konferencián (beleértve a regisztrációt, s a plenáris előadásokon és/vagy szekciókban való megjelenést);

3) az aktív figyelmet és hozzászólást mások prezentációihoz;

4) a saját prezentáció közzétételét;

5) a saját prezentációval kapcsolatos kérdésekre történő válaszadást;

6) esetenként (a konferencia előtt, vagy azt követő beadással) a prezentációval kapcsolatban írt tanulmány alkotását, lektorálás utáni megjelentetését (de: a tanulmányírás, közreadás nem mindig része a konferenciáknak).

Lehetséges tehát az is, hogy a választ nem adók között van, aki a konferenciát „teljesítettnek" vélte saját prezentációja közreadásával, s ezért nem törődött a nyilvános kérdésre történő nyilvános válaszadással. Ez személyes jelenléttel történő konferencián vagy annak felel meg, hogy az előadó prezentációja elhangzását követően elhagyja a helyszínt, s nem várja meg a kérdéseket; vagy annak, hogy az előadó az elhangzott kérdésekre nem akar, vagy nem tud válaszolni, s néma csendben álldogál.

d) A válaszok kis száma hátterében az unidiszciplináris szemlélet megszokottsága is állhat, szemben az interdiszciplináris szemlélet szokatlanságával. Egész iskolarendszerünk és felsőoktatásunk különálló diszciplinákra szabdalja a világot. Általános és középiskolában elszeparált tantárgyakkal, egyetemi képzésben elkülönült szakokkal találkozik a tanuló, hallgató. Miközben a fiatal kutatók az unidiszciplináris szemléletre szocializálódnak tizenkét éves(!) közoktatásbeli, s 3-6 éves felsőoktatásbeli (s talán további) karrierjük során, nehezen válthatnak a tudományközi szemléletmódra. Ennek egyik tüneti következménye lehet, hogy egy (a saját témától és/vagy diszciplinától talán távol álló) interdiszciplináris megközelítést igénylő nyilvános kérdésre meg sem kísérlik a válaszadást. Ez a lehetőség felveti a köz- és felsőoktatás felelősségét a holisztikus látásmódra, interdiszciplináris, távoli asszociációk képzésére is képes, kreatív, nyitott gondolkodású ifjúság nevelésével (helyesebben: elfojtásával) kapcsolatban!

e) A mesterséges intelligencia témakörben való járatlanság is állhat az alacsony válaszszám hátterében. Az előadások jóformán egyike sem foglalkozott konkrétan a mesterséges intelligencia témájával. Az is feltételezhetô (bár nem biztos), hogy a potenciális válaszadók döntő többsége érdeklődésén kívül esik a mesterséges intelligencia, s bár saját tudományterületükön belül kiváló szaktudással rendelkeznek, addig az MI témakörben laikusnak számítanak. Ezzel nincs is semmi probléma: lényegében a kőkorszak óta egyetlen személy sem - még a polihisztorok sem - birtokolhatják a teljes, egyetemes emberi kultúra minden elméleti és gyakorlati tudását. Elgondolkoztató azonban az, hogy a megadott 15 napos felkészülési idő - már, ha valóban volt annyi, s nem vitte el az erőforrásokat a járvány miatt megváltozott élethelyzet: lásd az a) pontot - 
mellett sem sikerült néhány mondatos (tehát nem disszertáció vagy tanulmány terjedelmû!) reflexiót adni. Jogosnak tűnő ellenérvként fogalmazhatják meg persze az ebbe a körbe tartozó „,választ nem adók”, hogy nem kívánnak hozzászólni olyan témához, amihez úgy érzik, nem értenek. Talán szakmai hírüket féltik, abból a szempontból, hogy esetleg téves, vagy a szakterületen elfogadott „főiránytól” eltérő nézeteket fogalmaznak meg, s szaktársaik ezt szóvá tehetik. Sajnos valóban megvan a lehetősége annak, hogy valaki tévedhet; ahogy annak is, hogy valaki esetleg nem téved, de nonkonform következtetésekre jut egy-egy témával kapcsolatban. Továbbá, valóban előfordulhat, hogy a kortársak felől kevés megértést kap az illető (mint ahogy az is megtörténhet, hogy az utókor valóban az úttörô szemléletű, s ehhez kellő magabiztossággal rendelkező tudósnak ad igazat).

f) Az alacsony válaszszám (remélhetöleg legkevésbé valószinü) oka lehet az is, hogy az átlagos fogyasztói magatartás berögzült viselkedésmintái léptek müködésbe: a vizsgálatban tapasztalt válaszadási arány lényegében azonos a direkt marketingben megszokott 30\% körüli önkéntes válaszadói aránnyal. Ez azonban azért nem valószínű, mert ez azt jelentené, hogy a résztvevôk többsége szempontjából nem mutatkozott különbség egy direkt marketing célú megkeresés és egy nemzetközi tudományos konferencia nyilvános kérdés-válasz helyzete között... Noha a tudományos karriert kezdő/gyakorló előadók esetében ez lehet a legkevésbé valószínű oka annak, hogy nem válaszolnak egy, az e-konferencia keretében feltett nyilvános kérdésre, mégis figyelemre mél- tó a 30\% körüli gyakoriság terén tapasztalható egybeesés.

\section{A kvalitativ adatelemrés \\ eredményeinek meguitatása}

A ,mesterséges intelligencia, mint cél” interdiszciplináris jellege ellenére is egy szúkebb kutatási terület, amire jelen vizsgálat alkalmával nem is érkezett válsz. A 42 értékelhető válasz 85\%-a a mesterséges intelligenciára, mint eszközre tekintett, és 15\%-uk utalt a mesterséges intelligencia és a világ kölcsönhatására. Az alábbiakban áttekintjük az értékelhető válaszok sokszínű világát (5. ábra).

Az „Egészség és orvostudomány” (Health and Medicine) szeleció résztvevői által adott válaszok, melyekben a mesterséges intelligencia, mint eszköz. jelenik meg. Az egészségre, illetve az orvostudományra fókuszáló szekciókban a mesterséges intelligencia alkalmazási lehetősége főként a diagnosztika, a terápia és a tanácsadás terén lehetséges.

A mesterséges intelligencia diagnosztikai célú alkalmazási lehetőségéről tesznek említést például az alábbi szerzők:

Baksa és tsai (2020) hosszútávú time-lapse imaging videomikroszkópos rendszerrel tanulmányozták szén nanocsövek aggregációjának hatásait a cornea regenerációja során. Mint írják, a jövőben olyan program fejlesztése is esedékes, amely „...feltanítva (...) felismerné például a sejteket és el tudná azokat különíteni a felesleges képi háttér információktól" (Baksa és tsai, 2020, 8. o.).

Polyák (2020) szintetikus nukleozid analógokat vizsgált citotoxikológiai aspektusból. Véleménye szerint (Polyák, 2020, 52. o.): „A 


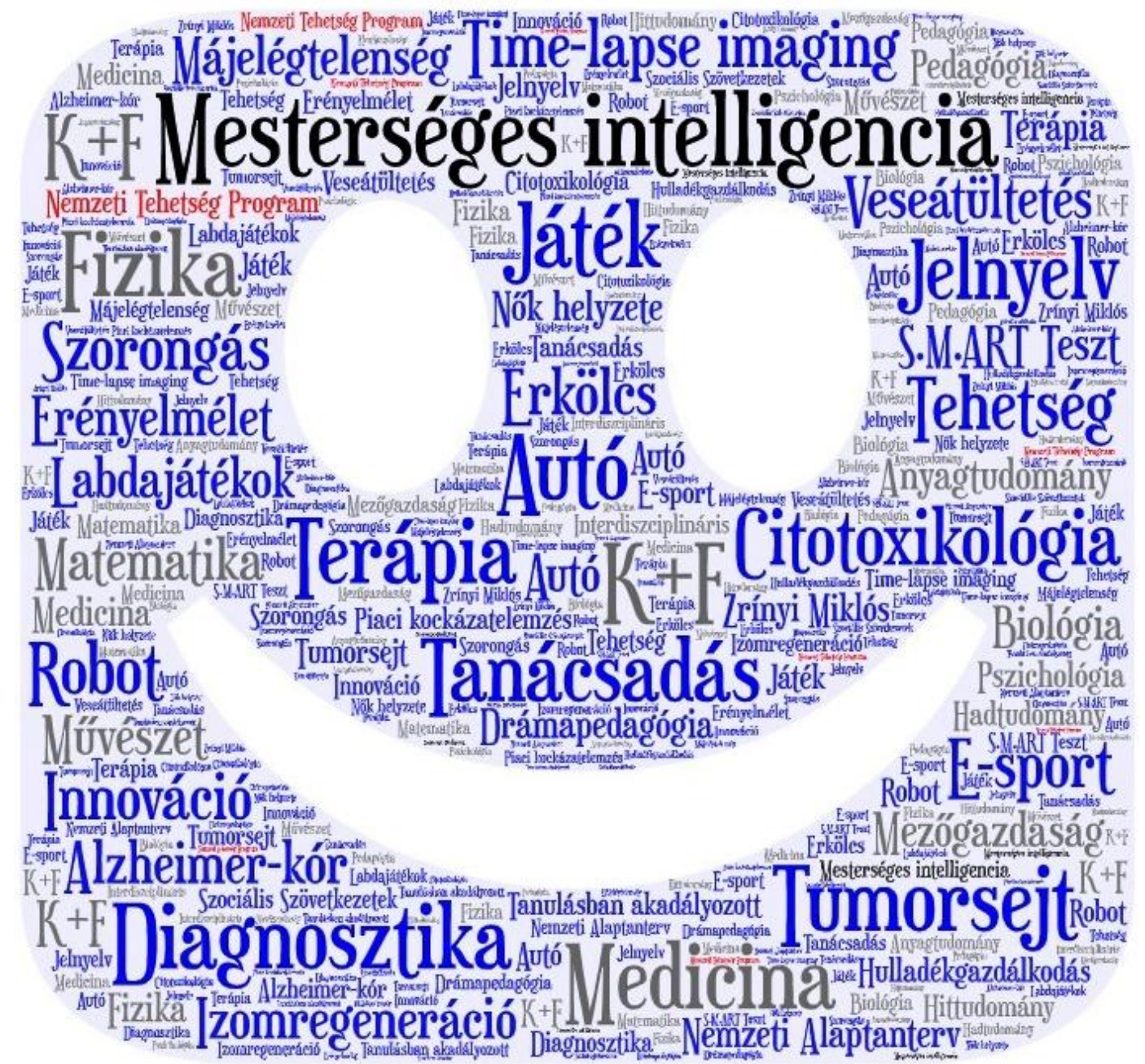

mesterséges intelligencia képes lehet felismerni a hatékony tumorellenes nukleozid analógokat már a szerkezetük alapján, ezzel felgyorsítva a kutatásokat. A time-lapse videómikroszkópia automatizálása után az elemzéseket egy program végezné, ami képes lenne felismerni a sejteket és a különböző folyamatokat (pl. apoptózis, nekrózis).”

Hinnah (2020) Alzheimer-kór esetében vizsgálta a TGF- $\beta$ útvonal változását. „Kutatásom egy jelentős része a jelátviteli útvonalak tanulmányozásán alapul. Ezek igen összetett rendszerek, mivel mind divergencia, 
mind konvergencia megfigyelhető bennük. Egyetlen szignálmolekula többféle receptort is aktiválhat bekötődésével, egy receptor aktiválódása több útvonalon is változásokat indukálhat, így például nem csak a sejtek számát befolyásoló faktor hathat azok méretére és életképességére is. Azonban ugyanez fordítva is igaz, több különböző szignál vezethet ugyanolyan eredményre. Mivel ezek a jelátviteli útvonalak több ponton kapcsolatban állnak egymással, minél több információja lesz róluk a tudománynak, annál átláthatatlanabbá válnak. Ebben látom a mesterséges intelligencia alkalmazásának lehetőségét, hogy a bonyolult módon egymásra ható, sokváltozós jelátviteli útvonalakon kialakuló hatás megértését és előrejelzését segítse.” (Hinnah, 2020, 22. о.).

Gyenes (2020) Mer Tirozin Kináz hiányos egér modellben vizsgálta a csökkent izomregenerációs jelenségeket. Meglátása szerint (Gyenes, 2020, 19. o.) „...a kutatás jövője a személyre szabott medicinában teljesedhet ki”, s elképzelhetőnek tartja, hogy ennek megvalósulásakor robotok térképezzék fel az adott egyén genomját.

Mehrabanian és Juhász (2020) mikro CT alkalmazásával vizsgált motorvezérlet endodontikai nagyítórendszereket. Felvetésük szerint, ebből a szempontból a mesterséges intelligenciát a foggyökér-csatorna anatómiájához jobban illeszkedő vizsgálatokhoz, vizsgálóeszközök előállításához lehetne alkalmazni.

A mesterséges intelligencia szereplehetôségét a terápia kapcsán fogalmazta meg néhány szerző. A tumorsejt növekedés ellen ható gyógyszerek hasznosulásának fokozása érdekében Egu, Kalmár és Király (2020) a terápi- ás hatást fokozó, egyben a mellékhatásokat csökkentő gyógyszeradagoló (mikrorészecskékből hatóanyagot felszabadító) rendszer kidolgozását kutatják, s lehetségesnek tartják a mesterséges intelligencia beépítését is kutatásukba, illetve a rendszerbe. Továbbá megjegyzik, hogy: „A mesterséges intelligencia segíthet abban, hogy emlékeztesse a betegeket a gyógyszereik szedésének idejére vagy a klinikai tünetek figyelésére" (Egu, Kalmár és Király, 2020, 15. o.).

Kabai (2020) az akut májelégtelenség aspektusából közelít az alternatív kezelési módokra. E területen a mesterséges intelligencia lehetséges szerepét abban látja, hogy a kezelések végzésére robotokat lehetne alkalmazni és az „emberi tényezőt ki lehetne hagyni az extracorporális kezelések kapcsán” (Kabai, 2020, 25. o.).

A mesterséges intelligencia a tanácsadást is szolgálhatja: Barth, Kállay és Nemes (2020, 9. o.) olyan online konzultációs rendszer fejlesztésérôl is beszámolt, amely a veseátültetéssel kapcsolatos szakmai döntéshozást, szakorvosok közötti konzultációt segítheti: „Maga a szoftver azonban továbbfejleszthető mesterséges intelligencia-alapú egészségügyi tanácsadásra specializálódó alkalmazássá is".

Végül előfordult olyan megközelítés is, amely a mesterséges és a humán intelligencia összevetésére fókuszált. Lepp és Némethné (2020) kosárlabdázók körében vizsgálta a scapularis diszfunkciót és a törzs-alsóvégtag stabilitását. Kosárlabdázás során érzékelési és információkat feldolgozó folyamatok alapozzák meg a motoros tevékenységet, ugyanakkor „a mesterséges intelligencia is képes lehet a szenzoros érzékelésre és információközlés- 
re” (Lepp és Némethné, 2020, 32. o.). E szerzők ugyanakkor hangsúlyozzák, hogy az információk emocionális feldolgozására a mesterséges intelligencia nem képes, szemben a humán idegrendszerrel, mely érzelmi válaszokat is produkál.

Hasonló következtetésre jutott Csontos (2020) miközben vízilabdászók és labdarúgók körében vizsgálta az alsó végtag sérülésmintáit és izomnyújthatósági jellemzőit. Mint írja (Csontos, 2020, 13. o.): „A mesterséges intelligencia is képes megtanulni labdajátékot játszani, sôt csapatban játszani is".

A „Környezet” (Environment) szekeció elöadói által adott válaszok, melyekben a mesterséges intelligencia, mint eszköz jelenik meg. E szekcióban egyaránt találhatók példák a mesterséges intelligencia felhasználására például a fizika, biológia és mezőgazdaság, anyagtudomány és matematika terén.

Firak és tsai (2020) azt mutatják be, hogy miként fedeztek fel egy új, X17 nevú részecskét a Magyar Tudományos Akadémia Atommagkutató Intézetében (MTA ATOMKI). Jelzik, hogy a gépi tanulási (machine learning) algoritmusok, neurális hálók fizikai kísérletekben történő felhasználására számos erőfeszítés történik napjainkban is.

Máté és tsai (2020) a szemes cirok genotípusok környezeti igényeinek összehasonlító elemzését tűzték ki célul. A precíziós mezőgazdasághoz is kapcsolódó kutatásuk és a mesterséges intelligencia közötti kapcsolatot a következők szerint vázolták Máté és tsai (2020, 36. о.): „A mesterséges intelligenciát, robotokat, önjáró mezőgazdasági gépeket akkor lehet sikeresen és megalapozottan használni a növénytermesztés során, ha jól ismer- jük, hogy mit szeretnénk tudni, mit szeretnénk mérni. A növényélettani paraméterek in vivo analízise, azok genotípus és környezeti tényező függésének többféle méréssel való meghatározása ezen az úton visz előre.” Lényeges kiemelni a fenti idézetnek azt az aspektusát, hogy az alap- és alkalmazott kutatások inputokat szolgáltathatnak a mesterséges intelligencia számára, aminek alkalmazása pedig segítheti az adott szakterületen megvalósuló további kutatási, hasznosulási lehetőségeket!

Szatmári (2020) a száradásos repedezés vizsgálata során a hálózatelmélet eszközeit használta fel a kialakult repedési mintázatok elemzésére. Megjegyzi, hogy: „A mesterséges intelligenciával kapcsolatos kutatások szintén a hálózatelmélet eszközeit használják fel gondoljunk itt a neurális hálókra" (Szatmári, 2020, 61. o.).

Uzonyi (2020) a Taylor-féle hatványtörvényt tesztelte random gráf modellekben és valódi (biológiai, szociális és infrastrukturális) hálózatokban. A kutatás során „a hálózatok osztályozásához a Label Propagation algoritmust használjuk, amely egy félig felügyelt gépi tanulási algoritmus" (Uzonyi, 2020, 68. o.).

A „Pedagógia, vallás és társadalom” (Pedagogy, Religion and Society) szekecióból érkezett válaszok, melyekben a mesterséges intelligencia, mint eszköz. jelenik meg.

Bodnár (2020) jelnyelvi (szleng)szótár készítésének műhelytitkait tárja fel. Témájának mesterséges intelligenciához kötése során a fordítóprogramokra hívja fel a figyelmet: „léteznek már jelnyelvről hangzó nyelvre realtime fordító programok (...), ez a 
jelnyelvkutatás alkalmazott nyelvészeti vonalának nagyon izgalmas kérdése" (Bodnár, 2020, 10. o.).

Sáfrány Judit (2020a) az iskolai környezetben jelentkező szorongásos tünetegyüttest vizsgálja. Felhívja a figyelmet arra, hogy: „A szorongásos tünetegyüttes a mesterséges intelligencia szempontjából ismeretlen jelenségnek tekinthető. A szorongás, mint érzelmi reakció moderáló hatása robotok esetében nem értelmezhető, így például a tanulási teljesítmény torzítás nélkül válik mérhetővé, stabil változóvá" (Sáfrány, 2020a. 55. o.).

Sáfrány (2020b) a szorongási rendellenességek és tudományos eredmények összefüggéseit is vizsgálta. Ezzel kapcsolatban jelzi, hogy: „A szorongási rendellenesség egy speciális emberi jelenség. A mesterséges intelligencia független lehet a stressz torzításától.

Számos tudományterület használja ezt az előnyt (például műtéti beavatkozások vagy automatikus pilóta)" esetében (Sáfrány, 2020b. 56. o.).

Sasné (2020) Nemzeti Alaptantervet, illetve az azzal kapcsolatban jelentkező mindennapi iskolai problémákat és jó gyakorlatokat foglalja össze. Meglátása, hogy nincs kapcsolat a témája és a mesterséges intelligencia között, mert véleménye szerint érzelmekre, hitre a mesterséges intelligencia nem képes.

Varga-Csikász (2020) a drámapedagógia tanári kompetenciákra gyakorolt hatását vizsgálja. Témája és a mesterséges intelligencia közötti összefüggések kapcsán egyrészt etikai kérdéseket vet fel (hogyan lehet egy mesterséges intelligencia erkölcsi szubjektum?), másrészt az MI-technológia használatának oktatási vonatkozásait emeli ki: „A technika és ember témájának körüljárása kiemelten fontos a jelenlegi generációk oktatása során, hiszen a technikai eszközök használata a mindennapunk részévé vált" (Varga-Csikász, 2020, 71. o.).

A „Tehetséggondozás és gyógypedagógia” (Talent Development and Special Education) squekcióból érkezett válaszok, melyekben a mesterséges intelligencia, mint eszközjelenik meg. A mesterséges intelligencia tehetségsegítéssel kapcsolatos felhasználási lehetőségei kapcsán a tehetségdiagnosztika és -gondozás is felmerült. Példa a diagnosztikai megközelítésre: Mező Ferenc és Mező Katalin (2020b) a K+F Stúdió innovációját, a kisiskolások kognitív és non-kognitív jellemzőinek vizsgálatára szolgáló művészeti mérőeszköz-rendszert, a S.M.ART vizsgáló eszközöket mutatják be. A múvészeti mérőeszköz fejlesztése a Magyar Képzőművészeti Egyetem által elnyert EFOP-3.2.6-16-201600001 projekt keretében valósult meg. A szerzők jövőbeli célja, hogy létrehozzanak egy „...mesterséges intelligenciát az adaptív tesztelés és a S.M.ART tesztek automatikus értékelése érdekében" (Mező és Mező, 2020, 40. o.).

A tehetséggondozást tekintve több válasz is született. Horváth $(2020,24$. o.) a Csáti Refi tehetséggondozó program tapasztalatai kacsán fejti ki abbéli reményeit, hogy talán a „programban részt vevő diákok néhány év múlva a mesterséges intelligencia kutatói, alkalmazói” lehetnek. Az iskolai vagy azon kívüli tehetséggondozó programok tárgya lehet tehát a mesterséges intelligencia következő (nemcsak felhasználó, hanem) kutató nemzedékének felkészítése. 
Mező Katalin (2020) a K+F Stúdió keretében Nemzeti Tehetség Program támogatásával megvalósuló (azonosító: NTP-NEER-190016) „Hölgyek a tudományban” tehetséggondozó programot mutatja be. E tehetséggondozó program és a mesterséges intelligencia kapcsolatának bemutatásakor felhívja a figyelmet arra, hogy: „A mesterséges intelligencia kutatásokba hölgyek eddig is bekapcsolódtak és továbbiakban is be fognak kapcsolódni. Gondoljunk pl. Ada Lovelace-re, aki már a 19. század elején aktív kutatónő volt, leírást készített az első mechanikai számítógéphez, és az első számítógép programozónak tekinthető. A »Hölgyek a tudományban« programnak is témája lehet a mesterséges intelligencia" (Mező K., 2020, 41. o.).

Mező Ferenc (2020) a Nemzeti Tehetség Program támogatásával (azonosító: NTPPKTF-19-0002) és a $\mathrm{K}+\mathrm{F}$ Stúdió által megvalósításra kerülő „Innovációs Stúdium” tehetséggondozó program tapasztalatait osztja meg. E stúdium mesterséges intelligenciát érintő vonatkozásai kapcsán kifejti, hogy „Az Innovációs Stúdium alkalmas arra, hogy a mesterséges intelligencia kutatásának, felhasználásának lehetőségeit is bemutassa a résztvevők számára” (Mező F., 2020, 39. o.). Ehhez természetesen az is segitséget jelent, hogy a stúdium működtetője, egyben a Mesterséges Intelligencia címú lapnak a kiadója is (a nyílt hozzáférésú - Open Access - lap a www.kpluszf.com honlapon keresztül ingyenesen elérhető).

A szekcióba a sajátos nevelési igényű - a hozzászólásokban közülük is jellemzően a tanulásban akadályozott - gyermekek, tanu- lók fejlesztésével kapcsolatban is bemutatásra kerültek prezentációk.

Fábián és Varga (2020) zenei téren vizsgálja a tanulásban akadályozott gyermekeket (a tehetséggondozás aspektusából is!): „A tanulásban akadályozott gyermekek zenei tehetsége és fejlesztése a mesterséges intelligencia mûvészeti irányú voltával hozható kapcsolatba” (Fábián és Varga, 2020, 16. o.), mindkettő elég idegen még az emberek számára.

Varga és Fábián (2020) a tanulásban akadályozott gyermekek vizsgálatát a vizuális területen mutatja be (hangsúlyozva azt az álláspontot is, hogy e gyerekek akár tehetségesek is lehetnek). Álláspontjuk szerint „A vizuális területen tehetséget mutató tanulásban akadályozott tanulók (...) a robotoktól az űrhajózásig mindent sajátjuknak érezhetnek, amíg a vizualitás eszközeivel megalkothatják azokat” (Varga és Fábián, 2020, 69.o.). E megközelítésben a mesterséges intelligencia a tanulók érdeklődését felkeltő foglalkozások témájaként (motivációs eszközeként) jelenik meg tehát.

Molnár (2020) a tanulásban akadályozott gyermekek tanítása esetében alkalmazható motiváló módszerekre koncentrál. Felveti, hogy: „...motiváló módszernek tekinthetünk akár egy internetes felületen alkalmazható játékot (pl.: learningapps-em). A feladatmegoldása során a számítógép folyamatosan értékeli a gyermeket (pl.: »Tökéletesen megoldottad a feladatot, nagyon ügyes vagy«)" (Molnár, 2020, 46. о.).

$A$ „Mesterséges intelligencia és informatikai kultúra" (Artificial Intelligence and IT Culture) szekecióból érkezett válaszok, melyekben a mesterséges intelligencia, mint esžöz jelenik meg. Mező Kristóf 
Szíriusz (2020) a jövő személygépjárműveivel kapcsolatos lehetôségeket villant fel. Felvetése szerint: „A mesterséges intelligencia a jövő járműveiben vélhetően egyre több feladat ellátására lesz képes. E funkciók közül egyesek közvetlenül a közlekedésre irányulnak majd, míg mások »luxus«, »extra« szórakoztató, illetve bizonyos munkavégzéssel (irodai munka, elsősegély végzés stb.) kapcsolatos funkciók lehetnek majd" (Mező K. Sz., 2020, 42. o.).

Krek (2020) a klasszikus szerepjátékra, mint egy letűnt műfajra tekint, illetve bemutatja annak újjáéledését a kétezres években. Krek (2020, 30. o.) szerint: „A videojátékok és a mesterséges intelligencia közötti kapcsolat szembetűnő. Az általam elemzett konkrét műfaj, a klasszikus szerepjáték (c-rpg) is felhasználja a mesterséges intelligencia kutatásának gyakorlati eredményeit. Amikor ugyanis a játékos karaktere egy ellenféllel elegyedik harcba, a harc nehézségét több tényező között az ellenfelet irányító mesterséges intelligencia adja".

Peter Pšenák (2020) az R szoftver alkalmazásának lehetôségét mutatja be a piaci kockázat elemzése, számszerüsítése esetében. „Ebben a szoftverben lehetőség van machine learninget alkalmazni a különböző rizikó kiszámításához, ezen felül automatizálható is a folyamat” (P̌̌enák, 2020, 51. o.).

Roskó (2020) a mesterséges intelligenciával kapcsolatos fejlesztéseket tekinti át három év távlatában. Ennek részeként tér ki a téma hulladékgazdálkodási kérdéseire - például: „A hulladékszigetek felderítésében is alkalmazható drónok által készített felvételeket tanulóalgoritmusokkal feldolgozva, a rend- szer humán erőforrás nélkül is képes lehet azonosítani az esetleges hulladéktelepeket, melyek felszámolására, szintén emberi beavatkozás nélkül is, odarendelheti a WasteShark gyűjtődrónokat" (Roskó, 2020, 54. о.).

A „Müvészet és történelem” (Art and History) szeekció elöadói által adott válaszok, melyekben a mesterséges intelligencia, mint esqköz jelenik meg

Lengyel Erik (2020) a marimba darabokban mutatja be a prelüd műfajának kiteljesedését. Rámutat arra, hogy „A prelüdök fejlődése technikailag egyre nagyobb feladatot állítanak az előadó elé. Lehet, hogy 10-15 év múlva már robotok játszanak egy-két előadási darabot, olyan nehéz és technikailag kivitelezhetetlen lesz az emberek számára" (Lengyel Erik, 2020, 31. o.).

Mátyus (2020) a mesének és a gyermeki léleknek az összefüggéseit fejti ki. Felhívja a figyelmet arra, hogy: „Elképzelhető, hogy mesei toposzok, elemek bekódolásával, meséket generáljon például egy robot. Viszont a meseírás folyamata közben az emberben lejátszódó valódi érzelmek, gondolkodási műveletek bonyolult egymásba fonódása nem lesz része a robot írási folyamatának. Ezáltal nem is tud olyan élményt nyújtani, amire egy ember által megírt mese képes" (Mátyus, 2020, 37. o.).

Mező Péter Dániel (2020) Zrínyi Miklós klasszikus művére, a „Szigeti veszedelem”-re fókuszál. „A mesterséges intelligencia az irodalmi, történelmi szövegfeldolgozást segítő kutatásokban lehet hasznosítható" - állítja, majd hozzáteszi: „Ezen kívül az írók, szereplők avatarjainak, szimulált személyiségeinek előállításában lehet szerepük a jövőben, ami 
oktatási és szórakozási célokat is szolgálhat" (Mező Péter Dániel, 2020, 45. o.).

Tóth Lilla (2020) „Megragadható pillanatok az impressziók hullámaiban" címú prezentációjához kapcsolódó mesterséges intelligencia vonatkozások után kutatva óva int bennünket attól, hogy a múalkotások elóállítását valaha egy az egyben a mesterséges intelligenciára bízzuk. Álláspontja szerint: „Témám a mûvészet és lélek szoros barátságát taglalja. Manapság az MI kora felfelé ível, de a mûvészet egy olyan területe életünknek, melyet teljes mértékben nem szabad átadnunk beprogramozott robotoknak. A robot ugyanis kódok által alkot, tökéletesen reprezentálja a valóságot, vagy több kép összemosásával egyedit hoz létre, mindezt azonban lelketlenül teszi. Igaz, a befogadóban generálhat érzéseket, de az alkotásban tátong egy űr, amit csak a lélek lenne képes megtölteni. Ezen túl nem tud az újdonság varázsával tekinteni a világra, ahogy egykor az impresszionisták tették" (Tóth, 2020, 66. o.).

Varga Imre Solt (2020) az adatgyüjtés és elemzés során látja felhasználhatónak a mesterséges intelligenciát. Témája: „Luxemburgi Zsigmond huszita hadjáratainak első fele (1420-1422) és a hadjáratokat befolyásoló földrajzi tényezők"

A „Család, közösség, jog és gazdaság” (Family, Community, Law and Economy) szekcióból érkezett válasz, amelyben a mesterséges intelligencia, mint eszközjelenik meg. Virág (2020) azokat a tényezőket kívánja azonosítani, melyek a szociális szövetkezetek megszűnése hátterében állhatnak. Véleménye szerint a mesterséges intelligencia használható lehet e szövetkezetek hatékonyságának fokozására és „élet- tartamának" növelésére. Virág (2020, 72. o.) szerint: „egy mesterséges intelligenciával rendelkező, konstruált szövetkezeti tag, ösztönző hatással lehet a többi munkavállalóra. A közösségi légkör ilyen fajta mesterséges intelligencia általi fejlesztésével (vagy egy tag helyettesítésével) a szociális szövetkezet teljesítményét növelhetjük, hatást gyakorolhatunk az interperszonális kapcsolatok pozitív irányba történő elmozdulására, ami az általános motiváltsági szintet emelheti. A mesterséges intelligencia hatással lehet a munkavállalói fluktuáció mérséklődésére, ezáltal a szövetkezetek tartós fenntartására is kedvező hatást gyakorolhat."

A mesterséges intelligencia és a világ kölcsönhatására mindössze hat válaszban találtunk utalást. Ezek a következők.

A „Pedagógia, vallás és társadalom” (Pedagogy, Religion and Society) szekcióból érkezett válasz. melyben a mesterséges intelligencia és a világ kölcsönhatása jelenike meg. Kovács (2020) erényelméletekkel és az arisztotelészi ítélkezésel-mélettel foglalkozó elemzése kapcsán a mesterséges intelligenciák felelősségre vonásának problémáját veti fel. Véleménye szerint: „A mesterséges intelligencia folyamatos fejlődése komoly kihívások elé fogja állítani a jogi szabályozást is. Úgy gondolom, e tekintetben különösen fontos lesz, hogy milyen elvek mentén hozzunk döntéséket, amelyben komoly segítséget jelenthet a filozófia alapjaihoz való visszatérés, hiszen teljesen újra kell majd gondolnunk jelenlegi ítélkezési rendszerünket" (Kovács, 2020, 28. o.).

A ,Tehetséggondozás és gyógypedagógia” (Talent Development and Special Education) szekcióból érkezett válaszok, melyekben a 
mesterséges intelligencia és a világ kölcsönhatása jelenik meg. Szakács Erika Tünde (2020, 60. o.) a Hölgyek a tudományban program egyik tagjaként Rosalind Franklin kutatónő bemutatására vállalkozott, s megjegyzi, hogy: „A prezentációmban bemutatott kutató nő, ha egy másik században élt volna amelyben a mesterséges intelligencia már nagyobb szinten áll talán sokkal messzebbre jutott volna a kutatásában."

Zsemján (2020) a tanulásban akadályozott gyermekek, tanulók integrált, inkluzív nevelését, oktatását vizsgálja Szabolcs-SzatmárBereg Megyében. Figyelemre méltó felvetése szerint „...maga az integrálás, és az inkluzív nevelés lehet a kulcspont a két téma között. Mivel a robotokat, tanulni képes algoritmusokat is be lehet építeni, illeszteni bizonyos közegekbe" (Zsemján, 2020, 75. o.).

Valóban: a robotok és egyéb MI entitások társadalmi elfogadása egyrészt felveti azok integrálásának kérdéseit, másrészt párhuzamba állíthatók a fogyatékkal élők integrálásának tapasztalataival.

A „Mesterséges intelligencia és informatikai kultúra” (Artificial Intelligence and IT Culture) szekcióból érkezett válasz, melyben a mesterséges intelligencia és a világ kölcsönhatása jelenik meg. A sportpszichológia és az esport kapcsolatát mutatja be például Csukonyi és Papp (2020). Az esport és a mesterséges intelligencia kapcsolata vonatkozásában megjegyzik, hogy: „Az e-sportban szükséges sportpszichológiai kompetenciák megfeleltethetőek a mesterséges intelligenciával való együttmúködés kívánatos kompetenciáinak. Ezen kompetenciák mérése és fejlesztése sportpszichológiai módszerekkel le- het a megoldás a jövőbeli mesterséges intelligencia ágensekkel való sikeres együttmúködés kialakításának" (Csukonyi és Papp, 2020, 14. o.). Az e-sporttal kapcsolatban lásd még: Bártfai és tsai, 2020).

A „Művészet és történelem” (Art and History) szekcióból érkezett válasz, melyben a mesterséges intelligencia és a világ kölcsönhatása jelenik meg. Pavlovics (2020) „A prométheuszi magatartás camus-i értelmezése" című prezentációja és a mesterséges intelligencia közötti összefüggést tekintve a következőt veti fel: „A robotok esetleges elterjedése erkölcsi kérdéseket is felvet. Például azt, hogy milyen területeken helyettesíthetik esetleg az embereket? Képesek-e arra, hogy helyettesítsék őket? És egyáltalán: szükség van-e arra, hogy az embereken kívül robotok is létezzenek? Az ókori görög mítoszok, így Prométheusz mítosza is, hagyományos értékeket és tulajdonságokat mutatnak be, ilyen például a bátorság, a felelősség, a boldogság kérdése.

A robotok esetében felmerül a kérdés, hogy: Még ha el is végzik az ember helyett a munkát (például felvesznek rendelést egy étteremben), rendelkezhetnek-e az említett jellemzőkkel? Bánhatunk-e velük úgy, mint az emberekkel, akiknek érzései vannak? Illetve, van-e a robotoknak is felelősségük vagy csak megalkotóiknak?” Pavlovics (2020, 50. o.).

A „Család, közösség, jog és gazdaság” (Family, Community, Law and Economy) sqekecióból érkezett válasz, melyben a mesterséges intelligencia és a világ kölcsönhatása jelenik meg. Mező Lilla Dóra (2020) a ghánai nők helyzetét elemzi a családtervezés, a gyermeknevelés és a munkaerőpiaci lehetőségek szempontjából. A mester- 
séges intelligencia vonatkozásában megjegyzi, hogy: „Ghánában a munkanélküliség nagy társadalmi probléma, amit a mesterséges intelligencia nem feltétlenül old meg, sôt. Utópisztikus megoldást jelenthet egy alapjövedelmet biztosító társadalmi modell alkalmazása Ghánában, illetve az, ha Ghána oktatási rendszere abba az irányba fejlődik, hogy az MI kutatás és előállítás világélvonalába kerüljön az ország. Sajnos mindkét vázolt megoldás valószínűsége csekély” (Mező Lilla Dóra, 2020, 44. o.).

\section{Konklúzió}

Noha a kérdésfeltevések és a tanulmány elsősorban a mesterséges intelligencia interdiszciplináris kapcsolódási lehetôségeire fókuszáltak, az eredmények általában véve a konferencia, e-konferencia részvételre és az interdiszciplináris szemléletmódra való beállítódásra vonatkozóan is hasznosíthatók.

Az e-konferencia ugyanolyan alkalmas fóruma lehet a tudományos eredmények közlésének, mint a személyes jelenléttel megvalósuló konferencia. Elméletileg az előbbi keretében is megvalósulhat a konferenciateljesítmények összessége.

Jelen vizsgálat tapasztalata azonban az, hogy a gyakorlatban a nyilvános kérdésekre történő válaszadás jellegű konferenciateljesítmény sok esetben elmaradt.

A jövőbeli konferenciák szervezésekor erre a konferencia-teljesítmény területre tehát kiemelt figyelmet célszerû fordítania a szervezőknek (például: a részvételi igazolás kiadásának feltételeként határozhatják meg a vá- laszadást - ami ebben az esetben azonban már nem lesz önkéntes).

A beérkezett értékelhető válaszok jól demonstrálják a mesterséges intelligencia interdiszciplináris jellegét. Ugyanakkor hasznos lehet az interdiszciplináris látásmód időnkénti hangsúlyozása. Ebben lehetnek szemléletformáló hatásúak az interdiszciplináris konferenciák (mint például az V. Nemzetközi Interdiszciplináris Konferencia), és az interdiszciplináris folyóiratok (mint például: OxIPO, Lélektan és hadviselés, Mesterséges intelligencia Open Acces e-folyóiratok).

\section{Korlátok, lehetőségek}

Jelen vizsgálatban egy konferencia nyilvánosan hozzáférhető adatait dolgoztuk fel, ami nem tette lehetővé, hogy néhány fontos háttérváltozót (például: életkor, végzettség, tudományos téren szerzett szakmai tapasztalat, korábbi konferenciatapasztalatok, diszciplina, nemzetiség stb.) is bevonjunk az adatelemzésbe. A jövőben e háttérváltozókra is kiterjedő vizsgálat is tervezhető.

További kutatási lehetőségként jelentkezik annak (kérdőív vagy interjú) révén történő feltárása, hogy a választ adó/nem adó résztvevők milyen motívumokat fogalmaznak meg válaszadási aktivitásukkal/passzivitásukkal kapcsolatban. E magyarázatok, mint adott viselkedésre vonatkozó énattribúciók (saját viselkedésre adott oksági magyarázatok) is elemezhetők lehetnek.

\section{Köszönetnyilvánítás}

Köszönetünket szeretnénk kinyilvánítani az V. Nemzetközi Interdiszciplináris Konferen- 
cia szervezőinek és résztvevőinek. Külön hálával tartozunk a vizsgálatban értékelhetô válaszokat küldő szerzőknek, akiknek gondolatai, olykor igen távoli asszociációi izgalmas intellektuális élményt jelentenek minden kellőképen nyitott olvasó számára.

\section{Irodalom}

Baksa Viktória, Ujlaki Evelin, Tóth Dominika Adelina és Szigeti-Turáni Melinda (2020): Szén nanocsövek aggregációjának hatásai a cornea regenerációja során. In: Mező Ferenc (szerk.): V. Nemzetközi Interdiszciplináris Konferencia: Nyilvános kérdések és válaszok gyüjteménye. 8. o. Letöltés: 2020.04.23. Web: https://drive.google. com/file/d/1xqrgPzC9uxoX7DNK71IE OUC3My-ZBAP2/view

Barth Anita, Kállay Márk és Nemes Balázs (2020): Veseátültetésre vonatkozó, szakmai döntéshozást támogató online konzultációs rendszer regionális vizsgálata veseelégtelenségben szenvedő betegek körében. In: Mező Ferenc (szerk.): V. Nemzetközi Interdiszciplináris Konferencia: Nyilvános kérdések és válaszok gyüjteménye. 9. o. Letöltés: 2020.04.23. Web: https://drive. google.com/file/d/1xqrgPzC9uxoX7DN K71IEOUC3My-ZBAP2/view

Bátfai Norbert, Csukonyi Csilla, Papp Dávid, Hermann Csaba, Deákné Osvald Erika és Győri Krisztina (2020): A DEACHackers esport szakosztály mesterséges intelligencia oktatási és kutatási elképzelése a Minecraftban. Mesterséges intelligencia interdiszciplináris folyóirat, II. évf. 2020/1. szám. 95-109. doi:10.35406/MI.2020.1.95
Bodnár Noémi (2020): Hogyan készül egy jelnyelvi (szleng)szótár?. In: Mező Ferenc (szerk.): V. Nemzetközi Interdiszciplináris Konferencia: Nyilvános kérdések és válaszok gyüjteménye. 10. o. Letöltés: 2020.04.23. Web: https://drive.google.com/file/d/ 1xqrgPzC9uxoX7DNK71IEOUC3MyZBAP2/view

Csontos Fruzsina (2020): Az alsó végtag sérülés-mintái és izomnyújthatósági vizsgálata labdarúgók és vízilabdázók körében. In: Mező Ferenc (szerk.): $V$. Nemzetközi Interdiszciplináris Konferencia: Nyilvános kérdések és válaszok gyüjteménye. 13. o. Letöltés: 2020.04.23. Web: https:// drive.google.com/file/d/1xqrgPzC9uxoX 7DNK71IEOUC3My-ZBAP2/view

Csukonyi Csilla és Papp Dávid (2020): Sportpszichológus vagy esportpszichológus? A sportpszichológia szerepe az esportban. In: Mező Ferenc (szerk.): V. Nemzetközi Interdiszciplináris Konferencia: Nyilvános kérdések és válaszok gyüjteménye.14. o. Letöltés: 2020.04.23. Web: https://drive.google. com/file/d/1xqrgPzC9uxoX7DNK71IE OUC3My-ZBAP2/view

Egu, John, Kalmár, József and Király, Gabor (2020): Controlled release of Methotrexate from functionalized Silica-gelatin Aerogel Microparticles applied against Tumor Cell Growth. In: Mező Ferenc (szerk.): V. Nemzetközi Interdiszciplináris Konferencia: Nyilvános kérdések és válaszok gyüjteménye. 15. o. Letöltés: 2020.04.23. Web: https://drive.google.com/file/d/ 1xqrgPzC9uxoX7DNK71IEOUC3MyZBAP2/view 
Fábián Fruzsina és Varga Boglárka (2020): Tanulásban akadályozott gyermekek vizsgálata zenei területen. In: Mező Ferenc (szerk.): V. Nemzetközi Interdiszciplináris Konferencia: Nyilvános kérdések és válaszok gyűjteménye. 16. o. Letöltés: 2020.04.23. Web: https://drive.google. com/file/d/1xqrgPzC9uxoX7DNK71IE OUC3My-ZBAP2/view

Firak, Daniel Scheres, Krasznahorkay, A.J., Csatlós, M., Csige, L., Gulyás, J., Koszta, M., Szihalmi, B., Timár, J., Nagy, Á., Sas, N.J. and Krasznahorkay, A. (2020): X17: the search for a new particle (and how scientist at MTA Atomki may have found it). In: Mező Ferenc (szerk.): V. Nemzetközi Interdiszciplináris Konferencia: Nyilvános kérdések és válaszok gyüjteménye. 18. o. Letöltés: 2020.04.23. Web: https://drive.google.com/file/d/1xqrgPz C9uxoX7DNK71IEOUC3My-ZBAP2/ view

Gyenes Dominik (2020): Csökkent izomregeneráció Mer Tirozin Kináz hiányos egér modellben. In: Mező Ferenc (szerk.): $V$. Nemzetközi Interdiszciplináris Konferencia: Nyilvános kérdések és válaszok gyüjteménye. 19. o. Letöltés: 2020.04.23. Web: https:// drive.google.com/file/d/1xqrgPzC9uxoX 7DNK71IEOUC3My-ZBAP2/view

Hinnah Barbara (2020): TGF- $\beta$ útvonal változása Alzheimer-kórban. In: Mező Ferenc (szerk.): V. Nemzetközi Interdiszciplináris Konferencia: Nyilvános kérdések és válaszok gyüjteménye. 22. o. Letöltés: 2020.04.23. Web: https://drive.google.com/file/d/ 1xqrgPzC9uxoX7DNK71IEOUC3MyZBAP2/view
Horváth László (2020): A Csáti Refi program tapasztalatai. In: Mező Ferenc (szerk.): V. Nemzetközi Interdiszciplináris Konferencia: Nyilvános kérdések és válaszok gyűjteménye. 24. o. Letöltés: 2020.04.23. Web: https://drive.google.com/file/d/1xqrgPz C9uxoX7DNK71IEOUC3My-ZBAP2/ view

Kabai Péter (2020): Akut májelégtelenség alternatív kezelési módjai. In: Mező Ferenc (szerk.): V. Nemzetközi Interdiszciplináris Konferencia: Nyilvános kérdések és válaszok gyüjteménye. 25. o. Letöltés: 2020.04.23. Web: https://drive.google.com/file/d/ 1xqrgPzC9uxoX7DNK71IEOUC3MyZBAP2/view

Kovács Zsófia Dóra (2020): Erényelméletek, avagy visszatérés Arisztotelészhez az ítélkezéselméletben. In: Mező Ferenc (szerk.): V. Nemzetközi Interdiszciplináris Konferencia: Nyilvános kérdések és válaszok gyűjteménye. 28. o. Letöltés: 2020. 04.23. Web: https://drive.google.com/ file/d/1xqrgPzC9uxoX7DNK71IEOUC3 My-ZBAP2/view

Krek Norbert (2020): Egy letűnt múfaj újjáéledése - A klasszikus szerepjáték műfaji konvencióinak alakulása a kétezres években. In: Mező Ferenc (szerk.): V. Nemzetközi Interdiszciplináris Konferencia: Nyilvános kérdések és válaszok gyüiteménye. 30.o . Letöltés: 2020.04.23. Web: https://drive. google.com/file/d/1xqrgPzC9uxoX7DN K71IEOUC3My-ZBAP2/view

Lengyel Erik (2020): Prelüd múfajának kiteljesedése marimba darabokban. In: Mező Ferenc (szerk.): V. Nemzetközi Interdiszciplináris Konferencia: Nyilvános kérdések és vála- 
szok gyüjteménye. 31. o. Letöltés: 2020.04.23. Web: https://drive.google. com/file/d/1xqrgPzC9uxoX7DNK71IE OUC3My-ZBAP2/view

Lepp Kitti és Némethné Gyurcsik Zsuzsanna (2020): Scapularis diszfunkció és a törzsalsóvégtag stabilitásának vizsgálata, intervenciója a kosárlabdázók körében. In: Mező Ferenc (szerk.): V. Nemzetközi Interdiszciplináris Konferencia: Nyilvános kérdések és válaszok gyüjteménye. 32. o. Letöltés: 2020.04.23. Web: https://drive.google. com/file/d/1xqrgPzC9uxoX7DNK71IE OUC3My-ZBAP2/view

Máté Ádám, Murányi Eszter, Zsembeli József és Veres Szilvia (2020): Szemes cirok (Sorghum bicolor (L.) Moench) genotípusok környezeti igényeinek összehasonlító elemzése. In: Mező Ferenc (szerk.): $V$. Nemzetközi Interdiszciplináris Konferencia: Nyilvános kérdések és válas zok gyüjteménye. 36. o. Letöltés: 2020.04.23. Web: https:// drive.google.com/file/d/1xqrgPzC9uxoX 7DNK71IEOUC3My-ZBAP2/view

Mátyus Magdolna: „Kettős tükör” : A mese és a gyermeki lélek In: Mező Ferenc (szerk.): V. Nemzetközi Interdiszciplináris Konferencia: Nyilvános kérdések és válaszok gyüjteménye. 37. o. Letöltés: 2020.04.23. Web: https://drive.google.com/file/d/ 1xqrgPzC9uxoX7DNK71IEOUC3MyZBAP2/view

Mehrabanian, Mojtaba and Juhász, Alexander (2020): Engine-driven rotary endodontics enlargement systems evaluation using micro CT. In: Mező Ferenc (szerk.): V. Nemzetközi Interdiszciplináris Konferencia: Nyilvános kérdések és válaszok gyüjteménye. 38. o. Letöltés: 2020.04.23. Web: https:// drive.google.com/file/d/1xqrgPzC9uxoX 7DNK71IEOUC3My-ZBAP2/view

Mező Ferenc (2019): Interdiszciplináris kapcsolódási lehetőségek a mesterséges intelligenciára irányuló cél-, eszköz- és hatásorientált kutatáshoz. Mesterséges intelligencia - interdiszciplináris folyóirat, I. évf. 2019/1. szám. 9-29. doi: 10.35406/MI.2019.1.9

Mező Ferenc (2020): Innovációs Stúdium In: Mező Ferenc (szerk.): V. Nemzetközi Interdiszciplináris Konferencia: Nyilvános kérdések és válaszok gyüjteménye. 39. o. Letöltés: 2020.04.23. Web: https://drive.google. com/file/d/1xqrgPzC9uxoX7DNK71IE OUC3My-ZBAP2/view

Mező Ferenc és Mező Katalin (2020a): V. Nemzetközi Interdiszciplináris Konferencia (Beszámoló). OxIPO - interdiszciplináris tudományos folyóirat, 2020/1, 5970. doi: 10.35405/OXIPO.2020.1.59

Mező Ferenc és Mező Katalin (2020b): S.M.ART - School, Measurement and Art (A new innovative measurement system of pupils' cognitive and non-cognitive characteristics). In: Mező Ferenc (szerk.): $V$. Nemzetközi Interdiszciplináris Konferencia: Nyilvános kérdések és válaszok gyüjteménye. 40. o. Letöltés: 2020.04.23. Web: https:// drive.google.com/file/d/1xqrgPzC9uxoX 7DNK71IEOUC3My-ZBAP2/view

Mező Katalin (2020): Hölgyek a tudományban. In: Mező Ferenc (szerk.): V. Nemzetközi Interdiszciplináris Konferencia: Nyilvános kérdések és válaszok gyüjteménye. 41. o. Letöltés: 2020.04.23. Web: https://drive. google.com/file/d/1xqrgPzC9uxoX7DN K71IEOUC3My-ZBAP2/view 
Mező Kristóf Szíriusz (2020): A jövő autói. In: Mező Ferenc (szerk.): V. Nemzetközi Interdiszciplináris Konferencia: Nyilvános kérdések és válaszok gyüjteménye. 42. o. Letöltés: 2020.04.23. Web: https://drive.google. com/file/d/1xqrgPzC9uxoX7DNK71IE OUC3My-ZBAP2/view

Mező Lilla Dóra (2020): „Változnak az idők”: a nők helyzete Ghánában. In: Mező Ferenc (szerk.): V. Nemzetközi Interdiszciplináris Konferencia: Nyilvános kérdések és válaszok gyüjteménye. 44. o. Letöltés: 2020.04.23. Web: https://drive.google. com/file/d/ 1xqrgPzC9uxoX7DNK71IEOUC3MyZBAP2/view

Mező Péter Dániel (2020): Zrínyi Miklós: Szigeti veszedelem In: Mező Ferenc (szerk.): V. Nemzetközi Interdiszciplináris Konferencia: Nyilvános kérdések és válaszok gyüjteménye. 45. o. Letöltés: 2020.04.23. Web: https://drive.google.com/file/d/ 1xqrgPzC9uxoX7DNK71IEOUC3MyZBAP2/view

Molnár Alexandra (2020): Motiváló módszerek a tanulásban akadályozott gyermekek tanítása során. In: Mező Ferenc (szerk.): $V$. Nemzetközi Interdiszciplináris Konferencia: Nyilvános kérdések és válas zok gyüjteménye. 46. o. Letöltés: 2020.04.23. Web: https:// drive.google.com/file/d/1xqrgPzC9uxoX 7DNK71IEOUC3My-ZBAP2/view

Pavlovics Zsófia (2020): A prométheuszi magatartás camus-i értelmezése In: Mező Ferenc (szerk.): V. Nemzetközi Interdiszciplináris Konferencia: Nyilvános kérdések és válaszok gyüjteménye. 50. o. Letöltés: 2020.04.23. Web: https://drive.google.com/file/d/
1xqrgPzC9uxoX7DNK71IEOUC3MyZBAP2/view

Polyák Lenke (2020): Újonnan szintetizált nukleozid analógok citotoxikológiai vizsgálata. In: Mező Ferenc (szerk.): V. Nemzetközi Interdiszciplináris Konferencia: Nyilvános kérdések és válaszok gyüjteménye. 52. o. Letöltés: 2020.04.23. Web: https://drive. google.com/file/d/1xqrgPzC9uxoX7DN K71IEOUC3My-ZBAP2/view

Pšenák, Peter (2020): Piaci kockázat és számszerűsítése az R szoftverrel. In: Mező Ferenc (szerk.): V. Nemzetközi Interdiszciplináris Konferencia: Nyilvános kérdések és válaszok gyüjteménye. 51. o. Letöltés: 2020.04.23. Web: https://drive.google.com/file/d/ 1xqrgPzC9uxoX7DNK71IEOUC3MyZBAP2/view

Roskó Tibor (2020): Mesterséges intelligencia fejlesztések három év távlatában. In: Mező Ferenc (szerk.): V. Nemzetközi Interdiszciplináris Konferencia: Nyilvános kérdések és válaszok gyüjteménye. 54. o. Letöltés: 2020.04. 23. Web: https://drive.google.com/file/ d/1xqrgPzC9uxoX7DNK71IEOUC3MyZBAP2/view

Sáfrány Judit (2020a): Szorongásos tünetegyüttes az iskolai környezetben. In: Mező Ferenc (szerk.): V. Nemzetközi Interdiszciplináris Konferencia: Nyilvános kérdések és válaszok gyüjteménye. 55. o. Letöltés: 2020.04. 23. Web: https://drive.google.com/file/ d/1xqrgPzC9uxoX7DNK71IEOUC3MyZBAP2/view

Sáfrány, Judit (2020b): Anxiety disorders and academic achievement. In: Mező Ferenc (szerk.): V. Nemzetközi Interdiszciplináris Konferencia: Nyilvános kérdések és válaszok 
gyüjteménye. 56. o. Letöltés: 2020.04.23. Web: https://drive.google.com/file/d/ 1xqrgPzC9uxoX7DNK71IEOUC3MyZBAP2/view

Sasné Venczel Ildikó (2020): Minden NA(p)T -i problémák, (jó) gyakorlati válaszok. In: Mező Ferenc (szerk.): V. Nemzetközi Interdiszciplináris Konferencia: Nyilvános kérdések és válaszok gyüjteménye. 57 . o. Letöltés: 2020.04.23. Web: https://drive.google. com/file/d/1xqrgPzC9uxoX7DNK71IE OUC3My-ZBAP2/view

Szakács Erika Tünde (2020): Rosalind Franklin. In: Mező Ferenc (szerk.): V. Nemzetközi Interdiszciplináris Konferencia: Nyilvános kérdések és válaszok gyüjteménye. 60. o. Letöltés: 2020.04.23. Web: https://drive. google.com/file/d/1xqrgPzC9uxoX7DN K71IEOUC3My-ZBAP2/view

Szatmári Roland (2020): Száradásos repedezés vizsgálata. In: Mező Ferenc (szerk.): V. Nemzetközi Interdiszciplináris Konferencia: Nyilvános kérdések és válaszok gyüjteménye. 61. o. Letöltés: 2020.04.23. Web: https:// drive.google.com/file/d/1xqrgPzC9uxoX 7DNK71IEOUC3My-ZBAP2/view

Tóth Lilla (2020): Megragadható pillanatok az impressziók hullámaiban. In: Mező Ferenc (szerk.): V. Nemzetközi Interdiszciplináris Konferencia: Nyilvános kérdések és válaszok gyüjteménye. 66. o. Letöltés: 2020.04.23. Web: https://drive.google.com/file/d/ 1xqrgPzC9uxoX7DNK71IEOUC3MyZBAP2/view

Uzonyi Noémi (2020): An empirical study of Taylor's power law in random graph models and real networks. In: Mező Ferenc (szerk.): V. Nemzetközi Interdiszcipliná- ris Konferencia: Nyilvános kérdések és válaszok gyüjteménye. 68. o. Letöltés: 2020.04.23. Web: https://drive.google.com/file/d/ 1xqrgPzC9uxoX7DNK71IEOUC3MyZBAP2/view

Varga Boglárka, Fábián Fruzsina (2020): Tanulásban akadályozott gyermekek vizsgálata vizuális területen. In: Mező Ferenc (szerk.): V. Nemzetközi Interdiszciplináris Konferencia: Nyilvános kérdések és válaszok gyüjteménye. 69. o. Letöltés: 2020.04.23. Web: https://drive.google.com/file/d/ 1xqrgPzC9uxoX7DNK71IEOUC3MyZBAP2/view

Varga Imre Solt (2020): Luxemburgi Zsigmond huszita hadjáratainak első fele (1420-1422) és a hadjáratokat befolyásoló földrajzi tényezők. In: Mező Ferenc (szerk.): V. Nemzetközi Interdiszciplináris Konferencia: Nyilvános kérdések és válaszok gyüjteménye. 70. o. Letöltés: 2020.04.23. Web: https://drive.google.com/file/d/ 1xqrgPzC9uxoX7DNK71IEOUC3MyZBAP2/view

Varga-Csikász Csenge (2020): A drámapedagógia hatása a tanári kompetenciák alakulására. In: Mező Ferenc (szerk.): V. Nemzetközi Interdiszciplináris Konferencia: Nyilvános kérdések és válaszok gyüjteménye. 71. o. Letöltés: 2020.04.23. Web: https:// drive.google.com/file/d/1xqrgPzC9uxoX 7DNK71IEOUC3My-ZBAP2/view

Virág Ádám (2020): A szociális szövetkezetek megszűnése mögött álló háttértényezők. In: Mező Ferenc (szerk.): V. Nemzetközi Interdiszciplináris Konferencia: Nyilvános kérdések és válaszok gyüjteménye. 72. o. Letöltés: 2020.04.23. Web: https://drive.google. 
com/file/d/1xqrgPzC9uxoX7DNK71IE OUC3My-ZBAP2/view

Zsemján Eszter (2020): A tanulásban akadályozottak integrált, inkluzív nevelése, oktatása Szabolcs-Szatmár-Bereg Megyében. In: Mező Ferenc (szerk.): V. Nemzetközi
Interdiszciplináris Konferencia: Nyilvános kérdések és válaszok gyüjteménye. 75. o. Letöltés: 2020.04.23. Web: https://drive.google. com/file/d/1xqrgPzC9uxoX7DNK71IE OUC3My-ZBAP2/view 